\title{
PROMOTING PARTNERSHIP WITH TRADITIONAL AUTHORITIES IN DEVELOPMENT PROJECTS: A MODEL FOR COMMUNITY INFRASTRUCTURE PROJECT DELIVERY IN GHANA
}

\author{
E. Osei-Tutu*, E. Adinyira, A. P. Ofori, R. Asamoah And S. J. Ankrah \\ (E. O. T., A. P. O., R. A. \& S. J. A.: Construction Division, Council for Scientific and Indus- \\ trial Research (CSIR) - Building and Road Research Institute (BRRI), Kumasi, Ghana; E. \\ A.: Department of Building Technology, Kwame Nkrumah University of Science \\ and Technology Kumasi-Ghana). \\ *Corresponding author'semail: fasota@yahoo.com
}

\begin{abstract}
Promoting partnership with traditional Authority Project (PPTAP) was designed to translate into reality the vision of having our traditional leaders play pivotal roles in community development. The project was to test the role that chiefs, queen mothers and other opinion leaders could play in the decentralization of community development. In spite of the presence of some challenges with respect to project implementation such as slow pace in the payment of counterpart fund contribution, this novelty achieved spectacular successes. This paper discusses the results of a questionnaire survey that looked at the role played by traditional authorities and community involvement in infrastructure development for 40 selected communities in Ashanti region under the PPTAP, with support from the International Development Agency (IDA) of the World Bank and the Government of Ghana. The paper concludes that the inclusion of traditional authorities in beneficiary communities helped in an accurate identification of community needs, minimization of cost incurred and high-quality workmanship as well as strengthened ownership. For community based development, the paper recommends a Tripartite Partnership (TTP), where Traditional Authorities work in tandem with the Public and Private Sector to ensure sustainable national development. PPTAP presents an excellent framework for such TPP arrangements.
\end{abstract}

Keywords: Traditional Authorities, Community Based Project, Infrastructure, Development.

\section{Introduction}

Governments world over, especially in developing countries, are faced with the uphill task of providing basic infrastructure and services for their people. An attempt to arrest this situation has seen an introduction of the private sector as well as international donor partners in the procurement of community infrastructure.
Community infrastructure development in Ghana has been largely plagued with lack of project success due to non-participation of beneficiary communities in the planning and implementation phases of the project. Participation increases perception of ownership which positively influences project success (Adinyira, 2008). In light of this, decentraliza- 
tion has been used as a means to promoting participatory decision making and implementation of programmes and projects by many governments. Decentralization serves as a pre-condition to ensure effective participation of the local people in decision making. Decentralization is thus, achieved by strengthening existing local institutions since local institutions serve as the main agents of decentralization.

Promoting partnership with traditional Authorities Project (PPTAP) is an innovative procurement route evolved from the vision to have traditional leaders play pivotal roles in community development. The project was to test the consequence of allowing chiefs, queen mothers and other opinion leaders play crucial roles in the decentralization of community development. After its successful implementation in 40 selected communities in Ashanti region, there was the need to conduct an impact assessment study to ascertain the achievement of the set objectives and to draw on useful lessons for community development, if any.

Since various infrastructural procurement models are currently being employed for community infrastructure delivery in Ghana, there was the need to undertake a comparative cost study between PPTAP and other funding agency projects. Other areas of PPTAP reviewed and compared to that of other procurement models in use were procurement routes and transparency; cost trends; project duration and completion; project workmanship and quality; community involvement in project implementation; and social, economic and physical dimensions.

\section{Project background}

Otumfuor Osei Tutu II, the Asantehene, on his ascension to the Golden Stool, expressed his prime concern about poverty, increasing rate of communicable diseases such as HIV/AIDS, lack of codification of traditional customs laws, amongst other issues. The Asantehene, therefore challenged chiefs in the Ashanti Kingdom to take the necessary steps to reduce poverty and also create awareness about communicable diseases such as HIV/AIDS (ADF IV, 2004). Most especially, the Asantehene expressed great concern about the fallen standards of education in Ashanti and Ghana as a whole.

During a visit to the Manyhia palace by the then Ghana Country Director of the World Bank, the Asantehene took the opportunity to express his concern about how traditional leaders were left out in the allocation of funds for projects in their communities. The Asantehene was of the view that the World Bank should try and consider Traditional Authorities in the implementation of developmental projects on a pilot basis. Otumfuor was quoted as saying - Politicians come and go but we the traditional leaders are always there.

The Vice-President of the World Bank however, called on the Asantehene that his challenge to the World Bank would be considered in a proposed Learning and Innovation Loan (LIL) portfolio which would be discussed with the government of Ghana (World Bank, 2009).

A Committee of Asanteman Council and Ashanti Regional Coordinating Council was therefore set up to elaborate on the Asantehene's vision. The outcome was incorporated into the World Bank Country Assistance Strategy (World Bank, 2009). 
In May 2001, the Asantehene travelled to World Bank Headquarters to press on the President and Vice-President of the World Bank to eliminate bureaucracies to see to the successful start of the project in Ghana. Asantehene's vision led to the establishment of the Promoting Partnership with Traditional Authorities Project (World Bank, 2009). The overall project goal was to improve the quality of life of rural people through sustained poverty alleviation and capacity building of the traditional authorities and efficient transfer and utilization of resources (World Bank, 2009).

\section{Dimensions of PPTAP}

PPTAP interventions were delivered to 40 communities in 35 paramountcies and 18 districts in the Asanteman Council. The various tangible and intangible interventions were in the areas of school infrastructure, teachers' quarters and relevant facilities, monitoring of children's growth and various other capacity building programmes (World Bank, 2009).

\section{Educational sector interventions}

Under the education component, the activities focused on renovation, reconstruction and or construction of classrooms, offices, 6 bedroom teachers' quarters, library, staff common room and boreholes. Each participating community had a school rehabilitated, reconstructed and/ or constructed boreholes and 10 to 20 -seater Aqua Privy Toilet Facilities were also constructed. In addition, text books, readers and furniture (dual desk for the classrooms, tables and chairs for the library and head teachers' offices) were supplied to the schools. Three communities namely Hwereso, Asamang and the Manhyia Palace benefited from solar energy supply thus mechanizing the water borehole facility to supply water to the larger community. Teacher incentives schemes were also instituted under the project. In addition, 700 needy pupils selected by head teachers and recommended by the School Management Committees from all the beneficiary communities benefited from stationery supplies ( 5 exercise books, 5 notebooks, 1 mathematical set and one school bag each). Scholarship schemes for needy children and girls' education were also instituted (World Bank, 2009).

\section{Health sector interventions}

Outputs under the health component included training of community members and other key stakeholders in growth monitoring of children 0-5 years, HIV/AIDS control, disease surveillance including malaria prevention and control. Teams of six to seven trained facilitators from the district health directorates supported the implementation of community based growth promotion aimed at ensuring improvement in child health, particularly their nutritional status. These facilitators also trained seven to ten volunteers in each of the participating communities to undertake growth monitoring of children. Inputs such as weighing scales and weighing pans were provided for their activities. Monthly growth monitoring of children 0-2 years and half-yearly for children 2-5 years was also covered by the project. On awareness creation and follow up on HIV/ AIDS, the Asanteman Council has entered into partnership with an NGO (Serwaa Ampem AIDS Foundation) to follow up on activities started under the PPTAP including mounting of bill boards and sensitization programmes (World Bank, 2009).

\section{Capacity building}

Capacity building activities included training of all traditional leaders (including all paramount chiefs, queen mothers, beneficiary community chiefs and queen mother 's), DCEs 
and Planning Officers of beneficiary districts as well as community members (mainly the monitoring committees) in community development issues such as needs assessment, roles in the government's decentralization process as well as maintenance of school property and the water facilities. Eleven volunteers from each community were trained in the maintenance of the water borehole facilities. Training of health volunteers in health specific issues, were also undertaken. Two education vans fitted with various audio and video equipment were also procured to facilitate HIV/AIDS sensitization and monitoring activities by the Project Implementation Unit (PIU). As part of the capacity building, Medium Term Development Plans were prepared for each community and paramountcy. The plans take into account the community needs and development plans. All the 35 paramountcies have their own development plans and each community has its own development plan. The capacities of the district assemblies were built to enhance their role in the planning, implementation, monitoring and evaluation of development interventions in the districts. The District Assemblies and Traditional Authorities now have very good database to inform development activities. Management Information Systems (MIS) were put in place to facilitate management of development activities in the beneficiary communities, districts and paramountcies (World Bank, 2009).

\section{Cultural heritage preservation}

Under the cultural heritage component, Traditional Councils were assisted to improve on the ability of communities to carry out programmes that would help them to preserve and benefit from their cultural heritage through the development of educational activities, curriculum in schools on cultural heritage, linkages to environmental degradation, private sector-community business partnerships for eco-tourism projects, artifacts and practices. A study on identification of cultural heritage assets was conducted and a report on cultural heritage assets of the participating paramountcies produced ready for publication. Studies have been conducted on traditional courts and customary laws codified to help the Traditional Authorities to review the operations of the traditional court system with a view to reducing the incidence of chieftaincy disputes and litigation. Training of craft artisans for employment generation has been undertaken. Four of such training have been organized in conjunction with the Ghana Handicrafts Exports Associations for Wood Carvers in Ashanti at AkyeawKrom for 75 participants, for handicraft producers at Atonso in the Kwabre District for 46 participants, for brassware producers at Sokoban-Krofrom-Ashanti for 37 participants as well as a three month training workshop for 50 deaf and disabled craft artisans in Kente weaving, tie and dye, sculpture and/ screen printing at Tewobaabi in the Kwabre District. The Lands Secretariat at Manhyia has been refurbished to help streamline land acquisition processes and ultimately improve revenue generation for the Asanteman Council (World Bank, 2009).

\section{Implementation Arrangement and Manage- ment}

In view of the partnership and decentralization goals of the pilot project, the Asanteman and the Akyem Abuakwa Traditional Councils were responsible for the implementation of the project components in their respective areas. Project Implementation Units were set up within their traditional structures. The councils were to report to the Government of Ghana and International Development Association on the 
progress of work. The Government of Ghana through the Ministry of Finance had the oversight responsibility for the implementation of the project. The Government ensured that the Traditional Authorities maintain policies and procedures for successful implementation of the project. Representatives of the Ministry of Education and Health were members of committees established by the Traditional Councils to provide guidance to the Councils on the project implementation. The Government-through the Ministry of Finance reviewed the results of the monitoring and evaluation system with a view to designing future programmes of support, and coordinating the activities of the implementing agencies with the assistance of the project managers (World Bank, 2009).

The management structure of the PPTAP has the Traditional Authorities in the communities at the centre of the management structure. They were involved in the project from the start to the finish, playing key roles in the decision formulation part of the projects. This galvanized the inhabitants of the communities to feel a sense of belonging to the project. The role played by the Project Consultants in the management of the projects was to provide consultancy services for the project. Their strict and intensive supervision led to a high quality of work achieved. The Project Implementation Unit (PIU) was able to resolve with the concerns of all parties to the project contributed to a large extent the success of the projects. Most contractors ensured proper planning of their projects resulting into completion of projects on schedule while those few ones which were not completed on schedule could be attributed to unforeseen occurrences (World Bank, 2009).

\section{Experimental}

A multiple research approach was adopted for this study. A comprehensive desk review of PPTAP was carried out by the authors. This review involved all documentation on the project. The documents reviewed among others included, procurement plans, implementation frameworks, project progress reports, minutes of project site meetings and periodic consultant reports. Unhindered access to these documentations was possible due to the various roles the authors played in the implementation of the programme. An analytical framework was designed and used in comparing various features of PPTAP with that of other infrastructural delivery models employed in the study communities. PPTAP projects were compared to projects under other procurement models along the following:

- Project management

- Project duration and completion

- Project workmanship and quality

- Procurement routes and transparency

- Community involvement in project implementation

- Social, Economic and Physical dimensions

The empirical investigation phase of this study involved the conduct of questionnaire survey and structured interviews with varied stakeholders. One set of questionnaires each were sent to consultants on Education, Cultural Heritage, Health and Capacity Building projects to solicit their views on the impact of the project and the project implementation model. 
According to Mukherjee, (1999) the best way to evaluate any community based programme is to allow for an evaluation by the communities themselves. Another set of questionnaires were thus sent to the focal persons (Chiefs and Assembly representative) in each of the 40 pilot communities in the Ashanti Region selected for PPTAP. Table 1 below shows the distribution of these questionnaires and their respective response rates.

Data gathered from the survey phase of the study was largely analyzed using descriptive statistics such as frequencies, mean, standard deviations and percentages. This allowed for a good exploration of the data collected for conclusions to be drawn.

TABLE 1

Distribution of Questionnaires

\begin{tabular}{lcccc}
\hline & $\begin{array}{c}\text { Questionnaires } \\
\text { Allocated }\end{array}$ & $\begin{array}{c}\text { Questionnaires } \\
\text { Distributed }\end{array}$ & $\begin{array}{c}\text { Questionnaires } \\
\text { Received }\end{array}$ & $\begin{array}{c}\text { Percentage of } \\
\text { Questionnaires } \\
\text { Received }\end{array}$ \\
\hline Consultant & 9 & 9 & 9 & 100 \\
Contractors & 29 & 23 & 23 & 79.3 \\
Chiefs \& & 40 & 30 & 29 & 72.5 \\
Assembly & & & & \\
Members & 78 & 62 & 61 & \\
Total & & & & \\
\hline
\end{tabular}

(Source: Author's Field Survey, 2006)

\section{Results and discussion}

This section of the report is devoted to a thorough analysis of data collected from the survey conducted. The outcome of the data analysis and discussion reveals the required facts and figures obtained from the survey which will inform subsequent decision making.

\section{Procurement route}

The transparency of the procurement route employed by PPTAP was assessed in three main areas, namely selection of consultants, selection of contractors and the role by the Project Implementation Unit in the selection process. Asanteman Council through PPTAP employed Innovations Design Services (IDS) in asso- ciation with the Building and Road Research Institute (BRRI) to provide architectural and engineering Services for PPTAP projects in 40 deprived communities in Ashanti region. IDS/BRRI was selected through a competitive bidding process which was assessed by an independent project team to have been fair and transparent. IDS/BRRI was responsible for the selection of contractors through National Competitive Bidding. The selection procedure was made based on the World Bank's recommended procedure.

\section{Funding Agencies in Catchments Areas}

The following funding programmes and agencies were observed to be involved in providing 
community based infrastructure projects in the 40 selected communities in Ashanti Region:
- Ghana Education Trust Fund (GET Fund)
- Village Infrastructure Programme (VIP)

- Ghana Poverty Reduction Strategy (GPRS)

- Highly Indebted Poor Country's Fund (HIPC Fund)

- District Assemblies Common Fund (DACF)
Comparative cost studies of PPTAP and HIPC Projects in 2004

Questionnaires were sent to the consultants and contractors on similar projects executed by different funding agencies in the 2004 fiscal year. This allowed for comparison of the cost of similar projects executed by the consultants and the contractors. The study revealed that the consultants and contractors had executed similar projects funded by HIPC in 2004. Table 2 compares the average project cost of PPTAP with HIPC projects.

TABLE 2

Average projects cost of PPTAG and HIPC, 2004

\begin{tabular}{|c|c|c|c|c|}
\hline Project Name & $\begin{array}{l}\text { Av. Project Cost } \\
\text { (PPAG) in GHe }\end{array}$ & $\begin{array}{l}\text { Av. Project } \\
\text { Cost HIPC } \\
\text { in GHe }\end{array}$ & $\begin{array}{l}\text { Variance } \\
\text { GHe }\end{array}$ & $\begin{array}{l}\% \\
\text { Variance }\end{array}$ \\
\hline $\begin{array}{l}\text { Construction of } 6 \text { unit classroom with } \\
\text { furniture }\end{array}$ & $40,800.00$ & $49,000.00$ & $8,200.00$ & -16.73 \\
\hline $\begin{array}{l}\text { Construction of } 3 \text { unit classroom with } \\
\text { furniture }\end{array}$ & $28,500.00$ & $38,000.00$ & $9,500.00$ & -25 \\
\hline $\begin{array}{l}\text { Construction of } 5 \text {-seater enviro loo toilet } \\
\text { facility }\end{array}$ & $8,000.00$ & $9,000.00$ & $1,000.00$ & -11.11 \\
\hline $\begin{array}{l}\text { Construction of } 10 \text {-seater enviro loo toilet } \\
\text { facility }\end{array}$ & $15,000.00$ & $15,800.00$ & 800.00 & -5.06 \\
\hline $\begin{array}{l}\text { Drilling of boreholes for community water } \\
\text { provision }\end{array}$ & $4,800.00$ & $6,400.00$ & $1,600.00$ & -25 \\
\hline Rehabilitation of existing projects & $20,000.00$ & $21,000.00$ & $1,000.00$ & -4.76 \\
\hline $\begin{array}{l}\text { Construction of } 5 \text {-seater aqua privy toilet } \\
\text { facility }\end{array}$ & $2,800.00$ & $4,500.00$ & $1,700.00$ & -37.78 \\
\hline $\begin{array}{l}\text { Construction of } 10 \text {-seater aqua privy toilet } \\
\text { facility }\end{array}$ & $5,000.00$ & $5,800.00$ & 800.00 & -13.79 \\
\hline $\begin{array}{l}\text { Construction of } 20 \text {-seater aqua privy toilet } \\
\text { facility }\end{array}$ & $10,500.00$ & $12,200.00$ & $1,700.00$ & -13.93 \\
\hline $\begin{array}{l}\text { Construction of four unit } 6 \text { classrooms } \\
\text { teachers' quarters }\end{array}$ & $12,500.00$ & $14,300.00$ & $1,800.00$ & -12.59 \\
\hline Construction of school playing field & 800.00 & 1,000 & $2,000.00$ & -20 \\
\hline
\end{tabular}

Source: Author's Field Survey, (2006) 
The comparative studies of PPTAP projects and HIPC Projects revealed an average difference of $-16 \%$ (Table 2). The analysis from the two projects revealed that all projects undertaken by the HIPC funded project estimated over the PPTAP projects, at the variance range of $-4.5 \%$ to $-37 \%$. This is a clear indication that Ghana Government overspent on the HIPC/GOG Projects as compared to that of the PPTAP Projects in the 2004 National Development Programme. The study revealed that causes of cost variance between the two projects were due to lack of proper planning and control adopted by the parties involved in the production process and less involvement of the beneficiary communities in the implementation strategy. In order to address cost overrun, proper cost control mechanisms should be instituted to ensure adequate appropriation of resources.

Cost, time and quality are the most important indicators of project success in construction (Kwakye 1999). A project is said to be successful when time, cost and quality are optimized such that the project is able to be completed within an acceptable cost limit, time frame and acceptable quality. Cost survey conducted on the projects revealed $7.8 \%$ (GH $\not 190,789.52)$ upward increment of the total cost of the project. The minimum cost variance on the projects was $3.4 \%$ (GHф1,828.49) while the highest cost variance was $18.6 \%$
(GH $\notin 34,846.38)$. The cost increment observed was due to fluctuations (due to delays and increases in prices of materials), and variations (additional work from the client). Communities where the PPTAP projects were undertaken did not interfere negatively with the project delivery but rather provided the right atmosphere for the contractors to execute their work.

\section{Projects duration and cost}

The duration for the pilot PPTAP projects was varying between 3-6 months. All the contractors submitted acceptable working programmes indicating output targets to be achieved within the project duration. The consultants ensured that contractors behind schedule completed on time. The study indicated as shown in Table 3 that $6.7 \%$ of the contractors completed within the estimated time. The study revealed, $6.7 \%, 23.3 \%, 10 \%$, $23.3 \%$ and $30 \%$ of the contractors exceeded the project duration by $10 \%, 20 \%, 30 \%, 40 \%$ and $60 \%$ of the contract duration respectively. The contractors assigned various reasons for the delay and extension of project execution time. Paramount amongst the reasons was lack of access to the project sites and unfavorable weather conditions. Most of the projects were located in the most deprived communities and inaccessible communities. Some communities can only be reached by water transport which posed difficulties to the contractors working in such communities. 
TABLE 4

Cost and time variance of 29 PPTAP projects in Ashanti Region

\begin{tabular}{|c|c|c|c|c|c|c|c|}
\hline Const. Works \& Lot & $\begin{array}{l}\text { Original } \\
\text { Contract Price } \\
(\mathrm{Gh} \phi)\end{array}$ & $\begin{array}{l}\text { Revised } \\
\text { Contract Price } \\
(\mathrm{Gh} \phi)\end{array}$ & $\begin{array}{l}\text { Variance } \\
(\mathrm{Gh} \phi)\end{array}$ & $\begin{array}{l}\% \\
\text { Variance }\end{array}$ & $\begin{array}{l}\text { Actual } \\
\text { Comple- } \\
\text { tion Time }\end{array}$ & $\begin{array}{l}\text { Revised } \\
\text { Comple- } \\
\text { tion Time }\end{array}$ & $\begin{array}{l}\text { Variation in } \\
\text { Duration }\end{array}$ \\
\hline $\begin{array}{l}\text { WB PPTA/AC/EDUC/ } \\
\text { LOT1 ASARE KWAKWA } \\
\text { CONST. }\end{array}$ & $27,706.40$ & $27,706.40$ & - & - & $30 / 11 / 04$ & $28 / 02 / 05$ & 3 months \\
\hline $\begin{array}{l}\text { WB PPTAP/AC/ EDUC/ } \\
\text { LOT2 }\end{array}$ & $59,900.60$ & $59,900.60$ & - & - & $30 / 11 / 04$ & $28 / 02 / 05$ & 3 months \\
\hline $\begin{array}{l}\text { KOJO MENSAH CONST. } \\
\text { LTD WB PPTAP/AC/ } \\
\text { LOT3 }\end{array}$ & $71,935.05$ & $71,935.05$ & - & - & $20 / 11 / 04$ & $28 / 02 / 05$ & 3 months \\
\hline ANVYLL LTD & 71.935 .05 & $71,935.05$ & - & - & $20 / 11 / 04$ & $28 / 02 / 05$ & 3 months \\
\hline $\begin{array}{l}\text { WB PPTAP/AC/EDUC/ } \\
\text { LOT4 PAAFOCON } \\
\text { CONST. LTD }\end{array}$ & $72,134.33$ & $72,134.33$ & - & - & $20 / 11 / 04$ & $28 / 02 / 05$ & 3 months \\
\hline $\begin{array}{l}\text { WB PPTAP/AC/EDUC/ } \\
\text { LOT5 }\end{array}$ & $64,088.50$ & $73,165.96$ & $9,077.50$ & 14.16 & $20 / 11 / 04$ & $28 / 02 / 05$ & 3 months \\
\hline $\begin{array}{l}\text { INSTANT LTD WB PP- } \\
\text { TAP/AC/EDUC/LOT6 }\end{array}$ & $84,640.53$ & $95,832.47$ & $\begin{array}{l}11 \\
191.94\end{array}$ & 13.22 & $30 / 11 / 04$ & $22 / 12 / 04$ & 1 month \\
\hline $\begin{array}{l}\text { JOKODWO CONST. } \\
\text { LTD WB PPTAP/AC/ } \\
\text { EDUC/LOT7 }\end{array}$ & $53,821.23$ & $55,649.72$ & $1,828.49$ & 3.39 & $30 / 11 / 04$ & $22 / 12 / 04$ & 1 month \\
\hline $\begin{array}{l}\text { BOAHEN CONST. } \\
\text { WORKS LTD }\end{array}$ & $62,949.24$ & $62,949.24$ & - & - & $20 / 12 / 04$ & $6 / 2 / 2005$ & 3 months \\
\hline WB & & & & & & & \\
\hline PPTAP/AC/EDUC/LOT8 & & & & & & & \\
\hline $\begin{array}{l}\text { AKUAKO NKETIA } \\
\text { CONSTWORKS LTD }\end{array}$ & $61,144.68$ & $72,819.31$ & $11,674.64$ & 19.09 & $30 / 11 / 04$ & $28 / 12 / 05$ & 1 month \\
\hline WB & & & & & & & \\
\hline PPTAB/AC/EDUC/LOT9 & & & & & & & \\
\hline UNCLE WUBAH ENT & & & & & & & \\
\hline $\begin{array}{l}\text { WB PPTAP/AC/EDUC/ } \\
\text { LOT10 ANIMFA CONST } \\
\text { WORKS }\end{array}$ & 61.144 .68 & $72,819.31$ & $11,674.64$ & 19.09 & $30 / 11 / 04$ & $28 / 12 / 05$ & 13 months \\
\hline
\end{tabular}

Source: GNA, (2005) 
An approach adopted to enhance the cash flow situation of the contractors towards fast delivery was advance mobilization. This was after advance mobilization guarantee had been submitted and approved by the project consultants. All the contractors were given advance mobilization. Payments were made to $66.7 \%$ of the contractors within the first 3 weeks. Out of this rate, $16.7 \%$ of the contractors were paid within 8 to 15 days, whiles $8.3 \%$ were paid within 16 to 21 days. These disbursement arrangements lead to a little variation in the planned disbursement as shown on Fig. 1.

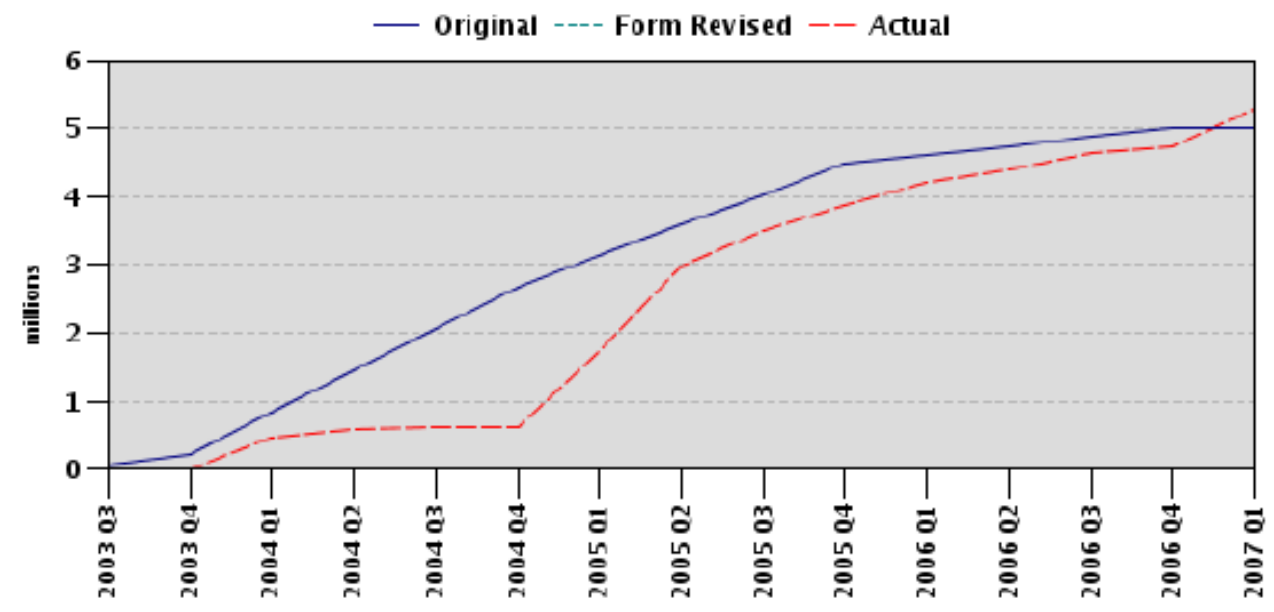

Fig. 1: Cumulative disbursement over the project life.

Source: Implementation completion and results Report (Ida-37439 Ida 0560).

It can be seen from the graph that starting from the March 2003, actual disbursement fell below the original disbursement. It can also be seen from the graph that there was a gradual improvement of disbursement from January 2005 through to January 2007, where there was a complete improvement. From the graph, in January 2007, the actual disbursement increased against the original disbursement. This improvement of the actual disbursement against the original disbursement was as a result of the advance mobilization guarantee submitted and approved by the project consultants to enhance the cash flow of contractors towards delivery on time.
On the other hand, under a similar project such as the Basic Education Support Project, in November 2006, sixteen percent instead of an expected eighty-two percent of projects had attained their delivery status (MOESS, 2006). In June 2007, twenty-four weeks beyond construction period, none of the twelve contracts had been completed (MOESS, 2007).

Similarly, in January 2008, eightyone days beyond construction period, only one contractor had successfully completed his contract. In all, one percent progress had been achieved within the reporting period (MOESS, 2008).

Still on the same project, in August 
2008, one hundred and nine days beyond the construction period, only three contractors had successfully completed their contracts. In fact, the overall project delivery average was only seventy-seven percent with less than one percent progress achieved within the reporting period (MOESS, 2008).

A critical analysis of the chronology of the poor outcome of the Basic Education Support Project can be attributed mainly to the delay in the payment of mobilization advance to contractors. This analysis reaffirms the pivotal role mobilization advance to contractors play in the timely delivery of projects by contractors.

\section{Project workmanship and quality}

Assessment of the quality of work and general workmanship on PPTAP projects was done by the consultants. However, the concerns of the communities with regards to quality of work were also taken into consideration. Consultants ensured that the contractors adhered to specifications. Generally, the consultants were satisfied with the quality of work. Up to $54 \%$ of people from the communities were highly satisfied with level of workmanship. A further $45 \%$ of beneficiaries considered quality of work to be averagely satisfied. Through the efforts of the consultants, the Project Implementation Unit and the communities, a high quality standard of workmanship was achieved on the PPTAP projects.

\section{Community involvement and cooperation}

PPTAP conducted initial sensitization programmes and as a result of this about $91 \%$ of the beneficiary communities already had knowledge about the project type of facility to be constructed in their communities and the main initiator (Asanteman Council). Communities elected focal persons (Assembly Mem- ber) who were involved in the all activities at the project sites, attending site meetings, organisation of communal labour, food for the workers and arranging for accommodation for the workers. This was to ensure active community participation at all stages of the project. Since perceived ownership positively influences community participation in community infrastructure delivery, PPTAP ensure communities felt personal ownership of the project from the start with the active involvement of the chief and other traditional authorities.

Impact on the lives of beneficiaries

Beneficiaries at the community, district and Traditional Authority levels hinted that the project had yielded significant impact on the lives of children, women, teachers and other community members. In the Ashanti region, the school infrastructure had increased access of children to education and had enhanced enrolment and retention of pupils in the beneficiary communities. Under Promoting Partnership with the Traditional Authority, recruitment and retention of qualified teachers had increased; the children were motivated to learn and had developed their reading culture as a result of the library, textbooks and reading materials made available. Punctuality of pupils and teachers to school had improved as a result of increased access to potable water by the teachers, pupils and women. The teachers' quarters had made the teachers more accessible to the children. The teachers do not spend on transport and get to school early leading to more contact hours with the pupils. Under Promoting Partnership with the Traditional Authority (PPTAP), healthcare services had been brought to the doorstep of the children, women/caregivers and the entire beneficiary communities. The work of the Community Based Disease Surveillance Groups together with the Growth Promoters had heightened awareness 
of community members about disease control and good care giving practices. Mothers now monitor the nutritional status and growth of their children regularly. Awareness about HIV/ AIDS had been heightened in the beneficiary communities and districts. This had led to a drop in the prevalence rate in most beneficiary communities.

Under Promoting Partnership with the Traditional Authority, development plans had been formulated for each participating community and paramountcy. The plans incorporate potential employment and income generation activities that would assist community development. Capacities of Traditional Authorities in the Asanteman Council in adjudicating land ownership disputes, succession cases and other issues brought before the Traditional Law Courts had also been strengthened. Business partnerships had been established with the private sector using outcomes of inventory on cultural heritage sites.

Project sustainability and future development

The project had put in place systems and structures, including implementation arrangements, with well-defined roles and responsibilities at the various levels, as well as leadership that could be sustained if ownership and commitment of the beneficiaries could be sustained. Contributions in cash and kind and performance of the key stakeholders point to their strong ownership and commitment. A number of sustainability measures and exit strategies had been put in place. These include budgetary allocations for project interventions at the District Assembly level, plans by the Directorate of the Ghana Education Service and the beneficiary schools to fund maintenance and repairs requirements under the Capitation Grant, as well as cash and in kind contribu- tions by the beneficiary communities for repair and maintenance of the facilities. The Directorate of the Ghana Health Service had also planned to budget for the growth monitoring, disease surveillance and HIV/AIDS activities. Linkage and coordination arrangements had been established by the Traditional Council and communities with the districts and other departments and agencies, including the Community and District Water and Sanitation Agencies, the Otumfuor Education Fund, the Ghana Book Trust and the German Development Service to support provision of the interventions. A number of challenges however confronted successful exit and sustainability of the project interventions. These included a slow pace in the payment of counterpart fund contributions by some districts, inadequate strategies for sustainability in some communities, weakened motivation of volunteers in the latter stages, and some reluctance to participate in some communities, including the failure to submit quarterly reports. (World Bank, 2007).

\section{Proposed implementation model for PPTAP projects}

The enactment of the local government Act (Act 462) places premium on the Metropolitan, Municipal and District Assemblies (M.M.D. As) as a pivot of local development for national growth (Osei-Tutu, 1998). In light of this central government continues to allocate huge sums of money to the M.M.D. As on the premise of self-motivation, self-realization and actualization as the main thrust of the national development process (Act 462). The PPTAP validated the laudable ideals of decentralization as a means of ensuring faster development of our communities and thereby enhancing the quality of life of our people. On the basis of the remarkable successes chalked 
by PPTAP, the model below is recommended for future programmes as means of strengthening decentralization process in Ghana.

Also, the following were some uncommon best practices adopted by PPTAP which are worth noting:

- Site visit (reconnaissance)

- Interaction and sensitization of beneficiary communities.
- Organization of a validation forum for participatory discussion for the design, study reports and drawings prepared by the consultant for approval and acceptance by the beneficiary communities.

- Pre-bid meeting to afford potential bidders, opportunities to seek clarification on bidding requirements.

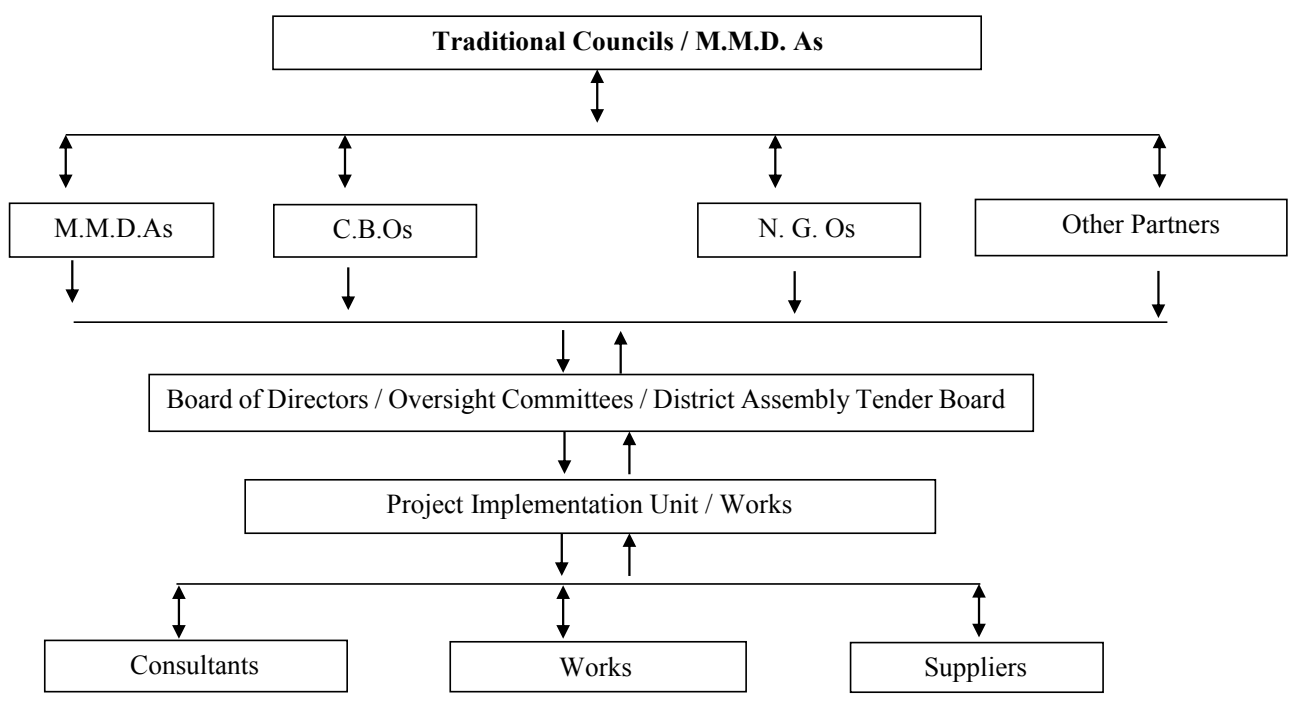

Fig. 2: Proposed Implementation Model for PPTAP Projects

Legend

M.M.D. As...............Metropolitan, Municipal and District Assemblies

C.B. Os................. Community Based Organizations

N.G. Os.................. Non-Governmental Organizations

Other Partners ........... e.g. European Union, Department for International Development

Source: World Bank, (2007) 


\section{Conclusion and recommendations}

PPTAP has revealed that the inclusion of Traditional Authorities and their communities in the decentralization process can speed up development. The involvement of Project Implementation Units in selection of consultants and contractors brought fairness and transparency in the process. Workmanship on PPTAP projects were generally good and this led to high quality work, though there were some time overruns. The involvement of the traditional authorities and the communities in the projects from the commencement to the completion resulted in the reduction of project cost as compared to other projects like HIPC funded projects. The impact of PPTAP can be seen in many facets of life including improvement of social, economic and physical development of the communities. This is evident in the increment observed in the number of classroom blocks, teachers' quarters, toilet and water facilities and the creation of jobs for some community folks.

On the basis of the findings of this study, a number of recommendations have been provided to facilitate replication and sustainability of the project approach and interventions. They include: the need to enhance participation of beneficiaries of project interventions from the very onset in order to secure their ownership, commitment and sustainability; the need to strengthen the exit and sustainability strategies such as mainstreaming projects into existing structures and developmental agenda; and the need to enhance the involvement of the Ministry of Local Government and Rural Development to facilitate its advocacy role for replication of the project approach. Traditional Authorities have very important roles to play in the success of any decentralization project. For sustained community development, an in- creasingly popular concept known as Tripartite Partnership (TPP), where Traditional Authorities work in tandem with the public and private sector to provide infrastructure development needs to be explored. The engagement of Traditional Authorities should not only be at a ceremonial level but as key partners in a structured partnership. Hence the interfaces at which different stakeholders in Ghana's community development agenda physically interact are critical to engendering wider participation in service provision and ought to be better developed in order to derive maximum benefits from this very innovative community infrastructure delivery model.

\section{References}

Adinyira, E. (2008) Selection of Appropriate Private Operators for Sustainable Water Service Delivery in Small Towns and Rural Communities. Unpublished $\mathrm{PhD}$ Thesis. Kwame Nkrumah University of Science and Technology.

AFRICAN DEVELOPMENT FORUM IV (2004) Governance for a progressing Africa. Addis Ababa, Ethiopia.

Bardhan, P. \& MookherJee, D. (2006) Decentralization and Accountability in Infrastructure Delivery in Developing Countries. Economic Journal 116 (508), 101 - 127.

Caporali, S.A., And Vergara, C. (1999) Essential Elements for the Sustainability of Small Water Systems In Cotruvo, F. et. al, (eds.) Providing Safe Drinking Water in Small Systems: Technology. Operations and Economic. London: Lewis Publishers.

GHANA NEWS AGENCY (2005) 95\% of projects under Promoting Partnership Authorities project completed. Regional News, Friday, 17/06/2005. http://www.modernghana.com/ newsthread2/80155/1/ (18/12/09). 
GHANA NEWS AGENCY (2005) Wolfowitz Commissions Basic School facilities at Nobowem in Ashanti region Regional. News, Wednesday, 14/03/2007.

GOVERNMENT OF GHANA (1993) Ghana local Government Act 1993, Act 462.

GOVERNMENT OF GHANA (2003) Public Procurement Act, 2003 (Act 663).

Osei-Tutu, E. (1998) Seminar on Construction Cost Reduction and Efficiency Enhancement on District Assemblies Development. Akyeawkrom-Ejsu-Kumasi.

Kwakye, A. A (1999). Construction Project Administration in practice. Longman Ltd. London.

WORLD BANK (2007) World Bank May 31, 2007 Implementation, Completion and Results Report.

WORLD BANK (2009) An Asanteman-World Bank Heritage Development Initiative in Promoting Partnership with Ghanaian Traditional Leaders Africa. Today - Volume 55, Number 4, summer 2009, pp. 3-26.
WORLD BANK (2009) Report (IDA-37430 IDA-H0560) For Promoting Partnerships with Traditional Authorities Project http://web. worldbank.org/external/project (18/12/09).

MINISTRY OF EDUCATION AND SCIENCE AND SPORTS (2006) Ministry of Education and Science and Sports Monthly Report: Construction of 6-Unit Classroom and 3-Unit Sanitation Blocks In the Ashanti and Brong Ahafo Regions. Funds and Procurement Management Unit- Basic Education Support Project.

MINISTRY OF EDUCATION AND SCIENCE AND SPORTS (2007) Ministry of Education and Science and Sports Monthly Report: Construction of 6-Unit Classroom and 3-Unit Sanitation Blocks In the Ashanti and Brong Ahafo Regions. Funds and Procurement Management Unit- Basic Education Support Project.

MINISTRY OF EDUCATION AND SCIENCE AND SPORTS (2008) Ministry of Education and Science and Sports Monthly Report: Construction of 6-Unit Classroom and 3-Unit Sanitation Blocks In the Ashanti and Brong Ahafo Regions. Funds and Procurement Management Unit- Basic Education Support Project.

Received 4 Apr 16; revised 20 Jan 20. 